\title{
Picture-induced semantic interference reflects lexical competition during object naming
}

\author{
Sabrina Aristei ${ }^{1}{ }^{*}$, Pienie Zwitserlood $^{2}$ and Rasha Abdel Rahman ${ }^{1}$ \\ ${ }^{1}$ Neurocognitive Psychology, Department of Psychology, Humboldt-Universität zu Berlin, Berlin, Germany \\ ${ }^{2}$ Psycholinguistics and Cognitive Neuroscience Unit, Institute for Psychology, Westfälische-Wilhelms-Universität Münster, Münster, Germany
}

\section{Edited by:}

Bradford Mahon, University of

Rochester, USA

Reviewed by:

Eduardo Navarrete, Universita di Padova, Italy

Tobias Bormann, Universitaetsklinik

Freiburg, Germany

${ }^{*}$ Correspondence:

Sabrina Aristei, Neurocognitive

Psychology, Department of

Psychology, Humboldt-Universität zu

Berlin, Rudower Chaussee 18, Berlin

12489, Germany.

e-mail: sabrina.aristei@hu-berlin.de
With a picture-picture experiment, we contrasted competitive and non-competitive models of lexical selection during language production. Participants produced novel noun-noun compounds in response to two adjacently displayed objects that were categorically related or unrelated (e.g., depicted objects: apple and cherry; naming response: "apple-cherry"). We observed semantic interference, with slower compound naming for related relative to unrelated pictures, very similar to interference effects produced by semantically related context words in picture-word-interference paradigms. This finding suggests that previous failures to observe reliable interference induced by context pictures may be due to the weakness of lexical activation and competition induced by pictures, relative to words. The production of both picture names within one integrated compound word clearly enhances lexical activation, resulting in measurable interference effects. We interpret this interference as resulting from lexical competition, because the alternative interpretation, in terms of response-exclusion from the articulatory buffer, does not apply to pictures, even when they are named.

Keywords: speech production, picture-picture interference, lexical competition, compound naming

\section{INTRODUCTION}

Many models of language production postulate that the retrieval of words from the mental lexicon is a competitive process that includes the selection of a target word from among co-activated, competing words (e.g., Dell, 1986; Starreveld and La Heij, 1996; Caramazza, 1997; Levelt et al., 1999). Models that incorporate lexical competition can easily account for inhibitory semantic-context effects often observed during picture naming. For instance, when in the picture-word-interference (PWI) paradigm, pictures are named while auditory or visual distractor words are simultaneously presented, naming is slower when the words are categorically related than when they are unrelated to the target (e.g., Schriefers et al., 1990; Roelofs, 1992; Damian and Martin, 1999; Levelt et al., 1999; Damian and Bowers, 2003). Lexical competition models explain such semantic interference as a consequence of the double activation of the distractor lexical entry, from the distractor itself and from the related target. This results in strong competing activation that delays the selection of the target word. Because unrelated distractors do not receive activation from the picture target, these competitors receive less activation and thus, interfere less with target selection.

However, recent failures to observe interference, and reports of facilitatory semantic-context effects have cast doubt on the lexical competition account of semantic-context effects in speaking (see Mahon et al., 2007 for a review). For instance, semantically related word distractors that are not category coordinates, such as associates (Alario et al., 2000; Abdel Rahman and Melinger, 2007) or distractors with a part-whole relation to the target (Costa et al., 2005), induce facilitation rather than interference. Based on these and other observations, an alternative model suggests that lexical selection is not competitive (Costa et al., 2005; Finkbeiner and Caramazza, 2006; Mahon et al., 2007; Janssen et al., 2008b). Semantic interference observed in PWI is instead explained in terms of the response-exclusion hypothesis (REH) put forward by Mahon et al. (2007). This account proposes that semantic interference observed in the PWI paradigm reflects a processing bottleneck in the articulatory output buffer. Critically, words (and thus distractors in the PWI paradigm) are assumed to have direct, automatic access to this buffer, blocking the articulation of the picture names. These words must be removed before articulation of the target picture name can start. Exclusion times are determined by criteria of response relevance, specified by task constraints and coarse semantic information. Category members of target utterances (e.g., "horse" for the target "cat") meet such constraints and are therefore more difficult to exclude from the articulatory buffer than unrelated words, giving rise to the interference effect. A prediction derived from the REH is that, given equal levels of response relevance (for instance, when all distractors are categorically related to the target), closely related distractor words should prime the target, and therefore induce facilitation, rather than interference. Thus, according to Mahon and colleagues, the important phenomenon to be explained is context-induced facilitation, because this effect arises at the lexical level. In contrast, semantic interference is assumed to arise post-lexically, as a result of the privileged access of words to articulatory processing. If this assumption holds, semantic interference induced by words is not informative about lexical-selection mechanisms.

With the present study, we test whether interference only arises when distractors have privileged access to articulation, as suggested by the response-exclusion account. To this end, we 
investigate semantic effects induced by pictures instead of words. While interference from one picture on the naming of another could be explained by lexical competition models (see Discussion below), the response-exclusion account predicts interference only for words but not for pictures. This is because only words, but not pictures, have privileged access to the articulatory buffer. When two pictures are presented simultaneously, there is no a priori reason to assume that the name of one has privileged access to this buffer. This is the case when pictures are merely context stimuli that should not be named - just as is the case for distractor words - but, critically, also when the pictures are to be named. In our paradigm, the names of two simultaneously presented pictures have to be combined into one novel-compound utterance (e.g., cherry-apple or cherry-box). In this case, nothing has to be removed from the response buffer (see below).

Empirical evidence for interference induced by pictures is scant. In contrast to the well-established inhibitory effects of categorically related distractor words in the PWI paradigm, context pictures typically induce no effects or, in some cases, facilitation (e.g., Damian and Bowers, 2003; La Heij et al., 2003; Navarrete and Costa, 2005, 2009; Meyer and Damian, 2007; Roelofs, 2008). For instance, directly contrasting distractor pictures and words, Damian and Bowers (2003) reported interference for categorically related words but not for pictures.

To our knowledge, there is only one report of semantic interference induced by picture-picture stimuli. Glaser and Glaser (1989) presented pictures to be named in the presence of to be ignored distractor pictures, and reported slower naming responses for semantically related relative to unrelated pictures. However, this effect has since not been successfully replicated. In fact, La Heij et al. (2003) argue that the effects obtained in Glaser and Glaser's study depended on response confusion, due to the use few stimuli, with picture pairs presented in close temporal succession. Thus, picture-induced semantic interference (based on the scarce evidence reported in literature) seems to strongly depend on specific task conditions.

Interference from context pictures has been reported in related paradigms such as the post-cue naming task. In this task, pairs of objects are presented in different colors, and a subsequent color cue indicates which object should be named (Humphreys et al., 1995; Dean et al., 2001; Hocking et al., 2010). Although the interference obtained was initially taken to reflect lexical competition (Humphreys et al., 1995), additional evidence suggested that it may be due to more general processes involved in the integration, in short term memory (STM), of the cue and the associated object attribute (Dean et al., 2001; Hocking et al., 2010). Thus, evidence for interference from context pictures that may be related to lexical-selection mechanisms remains scarce.

To summarize, semantic interference is often observed for distractor words, but there is no clear evidence for comparable effects by context pictures. This pattern fits the response-exclusion account, which assumes that words, but not pictures, have direct access to the articulatory buffer. Accordingly, semantic interference should be induced by word stimuli only. On the contrary, a semantic relation between target and context pictures should facilitate target processing. This should be most visible when there is no late articulatory bottleneck to hide such facilitation - as holds for picture stimuli. Therefore, related context pictures should induce facilitation, whereas related words should induce interference. This pattern may well depend on the (conceptual and lexical) activation induced by pictures.

As discussed above, differential effects of word and picture distractors have been interpreted as evidence against lexical competition models, but may not necessarily be inconsistent with such models. For instance, aspects of selective attention may play an important role in the picture-picture paradigm. Roelofs (2008) has demonstrated that semantically related (and unnamed) context pictures speed up gaze shifts that are considered to reflect shifts in selective attention. However, when participants were instructed to name both displayed objects, which should clearly increase the attention paid to - and the activation levels of - the context object, this facilitatory effect was no longer observed. Thus, attention directed to the context picture eliminates facilitation visible in gaze shifts for related relative to unrelated objects. These results suggest that a lack of semantic interference in the standard picture-picture paradigm may be due to the fact that distractor pictures are not activated strongly enough to induce sufficient lexical competition, and thus to produce detectable interference.

The most obvious explanation for the lack of interference would be that only the target concept, but not the concept of the context picture, is lexicalized in the picture-picture situation, when only one picture has to be named (cf. Bloem and La Heij, 2003). Consequently, no interference would be expected. Problematic for this proposal are findings of phonological context effects induced by pictures, in the absence of semantic effects (e.g., Morsella and Miozzo, 2002; Meyer and Damian, 2007; see Roelofs, 2008, for further discussion). Finally, it has been suggested that the absence of interference from context pictures is the result of a trade-off between conceptual facilitation and lexical interference (Navarrete and Costa, 2005, 2009). While pictures directly activate their conceptual representations, the activation of lexical representations proceeds indirectly, via. the conceptual level. Therefore, conceptual activation (associated with facilitatory effects) should be stronger than lexical activation (associated with inhibitory effects). This is reversed for word stimuli that activate their lexical representations directly and their concepts indirectly.

To summarize, evidence for semantic interference effects induced by pictures is scant. Distractor pictures typically have no effect or facilitate target picture naming. In line with the responseexclusion account, this might be due to the fact that pictures do not have privileged access to the output buffer whereas, at the same time, they activate conceptual and/or lexical representations, facilitating target naming when semantically related. Alternatively, picture-induced lexical competition may be weaker than the competition induced by words, and may be hidden by concomitant conceptual facilitation (Navarrete and Costa, 2005, 2009). Furthermore, unnamed context pictures may not receive sufficient attention to induce strong interference (e.g., Roelofs, 2008), or may not even be lexicalized (Bloem and La Heij, 2003).

In the present study, we employed a variant of the picturepicture paradigm to test for picture-induced semantic interference effects while avoiding the potential confounding factors discussed above. To distinguish between competitive and non-competitive accounts of lexical selection, we aimed at enhancing the chances for 
pictures to be attended and lexicalized, and thus, for their lexical representations to receive comparatively strong activation. We did so by asking participants to name pairs of pictures (e.g., a picture of an apple and a picture of a cherry, presented next to each other) by producing novel noun-noun compounds (e.g., apple-cherry). Importantly, novel compounds had to be produced for categorically related (cherry-apple) and unrelated (cherry-box) objects. Note that this study was carried out in German, a morphologically rich language where novel compounds (e.g., grape-tomato) are frequently generated from known individual concepts (cf. Wisniewski and Middleton, 2002; Gumnior et al., 2005). Note also, that the constituents of compounds are closely bound in German which is reflected by the use of linking elements (see Materials and Methods) and the fact that compounds are always written as one word: "Nussbaumholztisch" - nut tree wooden table). Therefore, in contrast to other task versions of the picture-picture paradigm, in which the context picture was either not named or named separately from the target picture, participants produced novel compound nouns, integrating both object names. The name of the object presented on the left side of the display always served as the modifier - always to be named first - and the name of the object on the right as the head of the compound. This procedure should minimize uncertainties as to which response should be given. Furthermore, participants need to retrieve both names in order to produce the novel compound correctly, ensuring attentive processing and lexicalization of both depicted objects.

According to competitive models, this procedure should enhance the chances for semantic interference effects to be observed. This is because both objects are attended to, and both are lexicalized. Thus, if lexical selection is competitive, compound naming should be slower for categorically related than unrelated pictures. In contrast, according to the response-exclusion account, pictures do not have privileged access to the articulatory buffer. Both are lexicalized and will enter the response buffer in a sequential order. Given their fixed position and naming order, their sequential access to the articulatory buffer is not hampered or delayed, and related pictures should not induce any inhibitory effects. Instead, categorically related pictures should speed up naming latencies relative to unrelated pictures.

\section{MATERIALS AND METHODS PARTICIPANTS}

Participants were 24 native German speakers (nine males; mean age: 22.7), who were paid or received course credits for their participation. All participants had normal or corrected-to-normal vision.

\section{MATERIALS}

Stimuli were 160 line drawings of objects (from the database of the Max-Planck Institute for Psycholinguistics, Nijmegen) from 14 semantic categories, scaled to fit into a $207 \times 207$ pixel frame $\left(4.5^{\circ}\right.$ visual angle at a distance of $\left.70 \mathrm{~cm}\right)$. Each object pair consisted of two drawings positioned next to each other. We created 160 categorically related and 160 unrelated object pairs, taking care that the selected object pairs did not constitute existing compounds (see Appendix). The unrelated condition was generated by reassigning related pairs. Grammatical gender congruency was balanced across conditions such that each object was included in a congruent and an incongruent pair, both in the related and unrelated condition (resulting in 80 related congruent pairs, 80 related incongruent pairs; the same for the unrelated condition). Each picture appeared equally often in the related and unrelated condition. The assignment of pictures to compound constituents was counterbalanced across participants, such that the same picture appeared equally often on the left (as modifier) and on the right side of the display (as head) in all conditions. Thus, because across participants all pictures were presented equally often as head and modifier in all conditions, alternative explanations of results in terms of factors such as constituent family size and frequency, constituent position (cf. Gagné, 2002; Krott et al., 2007) can be ruled out.

Phonological overlap between object names was minimized for word onset and word ending, as was the overlap between linking morpheme and picture name (onset and ending; unpaired $t$-tests: $p$ s $>0.5$ ). Furthermore, across conditions, an equal number of pairs required the production of a linking morpheme, linking heads and modifiers of German compounds (e.g., " $n$ " in Birne- $n$-apfel; pear apple). In both relatedness conditions, only the three most frequent German linking elements were required: null, $-n$, and $-s$ (lexical frequency in CELEX database: 65, 15, and $17 \%$ respectively). Changes in the root vowel via umlaut (e.g., hand + druck: händ-e-druck) or root reduction (subtractive linking element, e.g., birne + baum: birne-baum) did not occur. For one list the required linking morphemes were distributed as follows: " $\varnothing$ " - 108 cases in both conditions; " $n$ " 52 cases in both conditions. For the list with reversed picture positions the distribution was the following: “ $\varnothing$ " - related: 86 ; unrelated: 92 ; “ $n$ " - related: 70; unrelated: 64 ; and " $s$ " - related: 1 ; unrelated: 1 case $^{1}$.

We allowed visual similarity to vary freely. Visual overlap can affect picture naming, but there is no evidence that visual similarity influences picture-induced semantic-context effects. In fact, there is evidence from semantic blocking and post-cue naming that it does not (Humphreys et al., 1995; Damian et al., 2001; Vigliocco et al., 2004; Belke et al., 2005; Schnur et al., 2006; Hocking et al., 2010).

Furthermore, eight additional objects were selected to serve as training stimuli (see below).

\section{PROCEDURE}

Prior to the experiment, participants were familiarized with the visual stimuli and their names as follows: first, all individual objects were presented in random order on the screen and participants

\footnotetext{
${ }^{1}$ By reversing the relative picture position, the presence of linking morphemes was slightly larger for related than unrelated pairs (a difference of six pairs on a total of 160 pairs). To control whether this difference could drive our interference effects we analyzed response times with a mixed-design ANOVA including "picture positional order" as covariate and relatedness as within-subject factor. Results still yielded a main effect of relatedness $(F 1(1,22)=8.7, \mathrm{MSE}=1859, p=0.007)$ and a significant relatedness interaction with picture position $(F 1(1,22)=4.8, \mathrm{MSE}=9106$, $p=0.04$ ). This last effect reflects the larger interference effects for the list in which the two relatedness conditions were perfectly matched for the presence of linking morphemes (related-unrelated: $M_{\text {Diff }}=+41 \mathrm{~ms}$ ) compared with the reversed-position list $\left(M_{\text {Diff }}=+6 \mathrm{~ms}\right)$.
} 
Table 1 | Mean response times, SE of means, and mean error rates for related and unrelated pictures.

\begin{tabular}{llll}
\hline Picture relatedness & Mean RT (ms) & SE & ER (\%) \\
\hline Related & 1237 & 45.0 & 9.1 \\
Unrelated & 1211 & 45.3 & 9.5 \\
Difference & 26 & & -0.4 \\
\hline
\end{tabular}

were asked to name each of them. If necessary, they were corrected and the experimenter provided the intended object name. Next, participants were given printed sheets with all objects and their name printed below. Finally, they named all objects once again. After instructions, 24 practice trials were administered to familiarize participants with the task. Stimulus presentation and response recording was controlled with Presentation software (neurobehavioral systems). Each trial began with a fixation cross in the center of a light gray screen. After $500 \mathrm{~ms}$, a picture pair was presented until vocal response, with a maximum duration of $4 \mathrm{~s}$. Inter-trial interval (ITI) was $1500 \mathrm{~ms}$. Vocal responses were recorded with a microphone and naming latencies were measured with a voicekey. Naming accuracy and voice-key functioning were monitored online by the experimenter. Participants were instructed to fluently name the two objects by producing a compound noun (e.g., birne$n$-apfel) as fast and accurately as possible. They were informed that the object name on the left was always the modifier (and thus had to be spoken first), while the object on the right was always the head of the compound. Participants were not informed about the potential semantic relation between the two objects.

The whole session consisted in 320 trials and last for approximately $30 \mathrm{~min}$. The experiment was subdivided by short breaks, in which participants could rest. The order of object pairs was fully randomized for each participant individually.

\section{RESULTS}

Mean response times (RTs) for correct trials, SE of means, and mean percentages of errors in the experimental conditions are presented in Table 1. Trials with incorrect naming, stuttering, mouth clicks, or vocal hesitations (related: $8 \%$; unrelated: $8.75 \%$ ), and trials with voice-key failures or malfunctioning (related: $1.1 \%$; unrelated: $0.75 \%$ ) were discarded from the RT analysis.

Paired $t$-tests on RTs in the related vs. unrelated condition by participants $(t 1)$ and by items $(t 2)$ yielded significant relatedness effects $\left[M_{\text {Diff }}=26 \mathrm{~ms}, t 1(23)=2.7, p=0.01 ; t 2(159)=2.9\right.$, $p=0.004]$, with slower compound naming for categorically related than unrelated objects. Analyses of error rates showed no significant effect $\left(M_{\text {Diff }}=-0.4 \%\right.$; $\left.t \mathrm{~s}<1\right)$.

\section{DISCUSSION}

In the present study, we tested whether evidence for semantic interference effects in the picture-picture paradigm can be found when the lexical activation levels of simultaneously presented pictures was enhanced - in our case, by producing the names of both pictures as a nominal compound. Semantic interference would converge with the hypothesis that lexical selection is a competitive process. If, in contrast, facilitation arises in picture-picture paradigms, this would support the REH (see Mahon et al., 2007).
Therefore, employing a variation of the picture-picture paradigm allows us to test REH's assumptions, predicting picture-induced semantic facilitation when the output buffer is not blocked.

Categorically related and unrelated pairs of objects were named by producing novel compounds composed of the two object names (e.g., apple-cherry, tiger-dog). Thus, in contrast to previous studies with context pictures (e.g., Damian and Bowers, 2003; La Heij et al., 2003; Navarrete and Costa, 2005, 2009), the retrieval of both object names in close temporal succession was required for a single combined correct response. This resulted in a semantic interference effect, as it is typically observed for word distractors. As discussed above, picture-induced interference is in accordance with models of lexical selection that incorporate competitive mechanisms.

This is, to our knowledge, one of only two reports of pictureinduced interference, given that the majority picture-picture studies fail to observe interference effects (e.g., Damian and Bowers, 2003; La Heij et al., 2003; Navarrete and Costa, 2005, 2009; Roelofs, 2008). In contrast to the other direct evidence for interference by Glaser and Glaser (1989), our results are very unlikely due to confusion as to which picture name should be produced (here: which name should be produced first and which second). Participants always made the same type of response, producing the left picture name as modifier and the name of the picture on the right as head of the compound.

Our results support the assumption that previous null findings or facilitatory effects in the picture-picture paradigm may be due to insufficiently strong or absent co-activation of the competitors at the lexical level. As discussed above, weak lexical co-activation and the resulting weak interference may be additionally obscured by concomitant conceptual facilitation (e.g., Navarrete and Costa, 2005, 2009). Our data show that picture-induced inhibitory effects can be observed when both picture names are produced within one compound word, intensifying lexical activation of the pictures and, as a consequence, lexical competition. This idea fits well with recent reports pointing in the same direction. For instance, Oppermann et al. (2010) designed a study to investigate semantically mediated phonological effects in picture naming. They presented semantically related and unrelated picture pairs accompanied by auditory distractor words that could be phonologically related or unrelated to either the target or the distractor picture. Although it was not the main purpose of their study, Oppermann and colleagues analyzed semantic relatedness effects independently of the distractor-word condition (reported in their Discussion; p. 366). Their results revealed marginally significant semantic interference effects from to be ignored context pictures. Possibly, the presentation of distractor words and their potential phonological relation to the context pictures may have enhanced the processing of these pictures at the lexical and phonological level, and this might have been sufficient to reveal small interference effects. Thus, lexical competition induced by pictures that are not named may be a weak, but real phenomenon.

In contrast to lexical competition models, the REH cannot easily account for picture-induced interference. The REH is based on three central assumptions. First, distractor words - but not pictures - have privileged access to the single-channel articulatory buffer, blocking it for target-name articulation. Second, removal 
of the distractors from the buffer is most time consuming for response-relevant words, and response relevance is often determined by coarse categorical information. Therefore, it takes longer to remove related compared to unrelated distractor words. As in general, picture names do not have direct and privileged access to the articulatory buffer, they should not block it. It follows that no picture-induced interference should be observed, which is clearly in contrast to our findings. Of course, the names of both pictures were needed for the response in our task. According to the REH, accessing the output buffer per se does not imply the emergence of interference effects - if this were the case, how would it be possible to fluently produce multiple-word utterances? With the novelcompound production used here, the first picture name enters and leaves the articulatory buffer before the second proceeds to it, in an ordered manner. So, their sequential access to the buffer is not hampered or delayed, and no interference should arise. Moreover, in line with the third assumption, given equal levels of response relevance, a semantic relation between target and distractor - word or picture - induces facilitation at the conceptual and/or lexical level. As argued above, response relevance is only important for words that should not be named but differentially block the articulatory buffer, which is not the case for pictorial stimuli. Therefore, semantically related pictures should yield priming and therefore facilitate the naming response relative to unrelated pictures. This prediction is in clear contrast to our finding of inhibitory categorical relatedness effects from named pictures.

In contrast to standard picture-word and picture-picture interference paradigms, both picture names were needed for the response in our task. What does this imply for the articulatory buffer? Producing morphologically complex words involves the sequencing of morphemes for subsequent articulation (cf. Lüttmann et al., 2011). Even for those who do not believe in morphological composition during speaking (cf. Janssen et al., 2008a), novel compounds that do not possess a lexical entry have to be produced by combining and sequencing two lexemes - such as "tiger" and "dog." This implies that two lexemes are sent off for articulation, and the first one (the modifier) has to go in and out first. But crucially, nothing has to be removed, and even more crucially, articulatory processing is the same on related and unrelated trials. Thus, semantic relatedness is not at issue at the articulatory stage.

The only way to save the response-exclusion account is to postulate that the second-to-be-named object (the object on the right, and the head of the compound) is processed so rapidly up to the level of articulation that it blocks the articulatory buffer for the production of the compound modifier, which should be articulated first. In this case, the second picture name would indeed have to be removed from the buffer, and removal times might be longer for related than for unrelated pictures. However, we consider this option highly unlikely. First, it is unclear how precisely response relevance would affect task performance here. This is because both pictures are named, and therefore, related as well as unrelated picture names should be highly relevant. Thus, it would not even be clear whether categorical relatedness would still have an influence given that unrelated items are also relevant responses in this task context (see Aristei and Abdel Rahman, submitted, for a more comprehensive discussion on such aspects of response relevance). Second, such a "head-first" strategy goes against the ordering of compound constituents in the language, and would obviously be very costly and inefficient, without any advantage for task performance. Participants clearly knew which picture name should be produced first and which second (see Discussion above). Most importantly, there is evidence for a left-to-right processing preference for objects within one picture (Chatterjee, 2001). This preferred order corresponds to the order used in our study. Furthermore, during multiple picture naming, the order of mention determines the processing priority. That is, although the two pictures can be processed in parallel, higher priority is given to the first-to be named object, with the second object processed initially less extensively (Roelofs, 2007, 2008; Meyer et al., 2008; Malpass and Meyer, 2010). Therefore, we conclude that it is very unlikely that head-first strategies or insecurities about how to perform the task can explain the picture-induced interference effects observed here.

One might ask how the present findings relate to other reports of picture-induced interference effects. For instance, in the semantic blocking paradigm, in which all pictures are presented repeatedly and named one at a time, naming is slowed down in semantically homogeneous blocks of trials, consisting of category members, relative to heterogeneous blocks (e.g., Kroll and Stewart, 1994; Damian et al., 2001; Belke et al., 2005; Abdel Rahman and Melinger, 2007; Aristei et al., 2011). Semantic interference arises from the second picture presentation onward, while for the first presentation either no effect or semantic facilitation is usually observed (e.g., Abdel Rahman and Melinger, 2007; Aristei et al., 2011; for picture-induced semantic priming, see Sperber et al., 1979; Huttenlocher and Kubicek, 1983; Biggs and Marmurek, 1990). That is, repetitions are necessary in the semantic blocking paradigm, to build up semantic interference which then stabilizes typically after the second presentation. Likewise, interference is observed when semantically related objects are presented and named in a sequence: response latencies linearly increase with progressive order positions of related objects in a sequence (cumulative inhibition; e.g., Howard et al., 2006; Navarrete et al., 2010; Oppenheim et al., 2010). Thus, even though the pictures are presented in isolation in these tasks, the interference observed might be closely related to the present findings. The prior naming of category members may increase lexical competition in a similar way as the combined production of a compound name in the present study. However, the aim of the present study was to create a situation that comes very close to the PWI situation, and this makes it different from these related paradigms. Thus, other factors such as competitive learning (see Oppenheim et al., 2010, for a discussion), not directly related to lexical processes, may play an important role in these tasks that are not relevant here.

Presumably more relevant for the present study, Freedman et al. (2004) have reported interference effects for the production of conjoined noun phrases in response to two semantically related relative to unrelated pictures (e.g., "the apple and the pear"). However, we would like to point out that there is a critical difference between the two paradigms. Our procedure does not involve phrasal production, which requires additional processes and renders a direct comparison between the two interference effects problematic (see also Roelofs, 2008 p. 361 for a discussion of Freedman et al., 2004 study). Thus, Freedman and colleagues 
proposed the inclusion of STM buffers to account for their semantic interference effects. While such an explanation might hold for interference effects in phrasal production, this does not seem to be a relevant factor for the production of compounds.

To summarize, the interference effects reported in the paradigms discussed above contrast with the null or facilitatory effects usually reported in the picture-picture paradigm (e.g., La Heij et al., 2003; Roelofs, 2008) and may be related, at least to some extent, to the present finding of interference in novel compound production. However, these paradigms differ substantially from each other and from the present task, and it seems difficult to interpret all these findings as reflecting similar underlying mechanisms (see also Humphreys et al., 1995; Dean et al., 2001; Hocking et al., 2010; cf. Introduction).

Another aspect of relevance to our task concerns differential effects of thematic relations (e.g., FOR-relation: finger-ring can be paraphrased as "ring FOR fingers") between the constituents of the compounds in the two conditions. In particular, Gagné and colleagues (Gagné, 2002; Gagné and Spalding, 2004, 2009) assume that frequent thematic relations facilitate the processing (in comprehension) of novel compounds at the semantic level. Applying their logic to the production of novel compounds, we should find more (and more frequent) thematic relations between the compound constituents in the unrelated condition than in the related condition - given that in our study responses were faster in the unrelated condition. This is not supported by the data. A post hoc classification of all compounds according to Levi's (1978) relational categories as reported by Gagné and Spalding (2009) revealed that the related condition had a larger potential of thematic relations (211 across the two positional orders), with

\section{REFERENCES}

Abdel Rahman, R., and Melinger, A. (2007). When bees hamper the production of honey: lexical interference from associates in speech production. J. Exp. Psychol. Learn. Mem. Cogn. 33, 604-614.

Alario, F.-X., Segui, J., and Ferrand, L. (2000). Semantic and associative priming in picture naming. Q. J. Exp. Psychol. 53A, 741-764.

Aristei, S., Melinger, A., and Abdel Rahman, R. (2011). Electrophysiological chronometry of semantic context effects in language production. J. Cogn. Neurosci. 23, 1567-1586.

Belke, E., Meyer, A. S., and Damian, M. F. (2005). Refractory effects in picture naming as assessed in a semantic blocking paradigm. Q. J. Exp. Psychol. 58A, 667-692.

Biggs, T. C., and Marmurek, H. H. C. (1990). Picture and word naming: is facilitation due to processing overlap? Am. J. Psychol. 103, 81-100.

Bloem, I., and La Heij, W. (2003). Semantic facilitation and semantic interference in word translation: implications for models of lexical the frequent "IS" category being predominant (133 pairs). Of the unrelated pairs that could be bound by a thematic relation ( 83 pairs) the majority showed a "FOR" relation (44 pairs). Given this distribution, compound processing should have been easier in the related condition, but we found interference instead.

Similarly, it can be argued that the two relatedness conditions might differ in the semantic plausibility of the resulting compound (for plausibility in compound comprehension see, for example, Gagné and Shoben, 1997; Wisniewski and Murphy, 2005). Although the selected object pairs did not correspond to existing compounds, some might be more plausible than others, most likely those with related objects (e.g., parrot-eagle: an eagle with colorful plumage) than those with unrelated objects (e.g., pliers-eagle). Again, it seems reasonable that a higher semantic plausibility would make the novel compounds more acceptable, and thus facilitate their production (akin to compound comprehension). Thus, compounds with related objects should be named faster than those with unrelated objects, but our data show interference instead. If thematic relations or plausibility had a positive effect, this would have counteracted, and thus underestimated, the interference effect.

In conclusion, we demonstrate here that not only words but also pictures can induce semantic interference effects. This finding supports models assuming competitive mechanisms at the level of lexical selection, and is hard to reconcile with a localization of semantic-interference effects at the articulation level.

\section{ACKNOWLEDGMENTS}

This work was supported by grants AB277 4 and 5 from the German Research Foundation (DFG) to Rasha Abdel Rahman. related items in object identification. J. Exp. Psychol. Learn. Mem. Cogn. 27, 733-743.

Mem. Lang. 48, 468-488.

Caramazza, A. (1997). How many levels of processing are there in lexical access? Cogn. Neuropsychol. 14, 177-208.

Chatterjee, A. (2001). Language and space: some interactions. Trends Cogn. Sci. (Regul. Ed.) 5, 55-61.

Costa, A., Alario, F.-X., and Caramazza, A. (2005). On the categorical nature of the semantic interference effect in the picture-word interference paradigm. Psychon. Bull. Rev. 12, 125-131.

Damian, M. F., and Bowers, J. S. (2003). Locus of semantic interference in picture-word interference tasks. Psychon. Bull. Rev. 10, 111-117.

Damian, M. F., and Martin, R. C. (1999). Semantic and phonological codes interact in single word production. J. Exp. Psychol. Learn. Mem. Cogn. 25, 1-18.

Damian, M. F., Vigliocco, G., and Levelt, W. J. M. (2001). Effects of semantic context in the naming of pictures and words. Cognition 81, B77-B86.

Dean, M. P., Bub, D. N., and Masson, M. E. (2001). Interference from

Dell, G. S. (1986). A spreadingactivation theory of retrieval in sentence production. Psychol. Rev. 3 283-321.

Finkbeiner, M., and Caramazza, A. (2006). Now you see it, now you don't: on turning semantic interference into facilitation in a Stoop-like task. Cortex 6, 790-796.

Freedman, M. L., Martin, R. C., and Biegler, K. (2004). Semantic relatedness effects in conjoined noun phrase production: implications for the role of short-term memory. Cogn. Neuropsychol. 21, 245-265.

Gagné, C. L. (2002). Lexical and relational influences on the processing of novel compounds. Brain Lang. 81, 723-735.

Gagné, C. L., and Shoben, E. J. (1997). Influence of thematic relations on the comprehension of modifier-noun combinations. J. Exp. Psychol. Learn. Mem. Cogn. 23, 71-87.

Gagné, C. L., and Spalding, T. L. (2004). Effect of relation availability on theinterpretation and access of familiar noun-noun compounds. Brain Lang. 90, 478-486.
Gagné, C. L., and Spalding, T. L. (2009). Constituent integration during the processing of compound words: does it involve the use of relational structures? J. Mem. Lang. 60, 20-35.

Glaser, W. R., and Glaser, M. O. (1989). Context effects in Stroop-like word and picture processing. J. Exp. Psychol. Gen. 118, 13-42.

Gumnior, H., Zwitserlood, P., and Bölte, J. (2005). Assimilation in existing and novel German compounds. Lang. Cogn. Process. 20, 465-488.

Hocking, J., McMahon, K. L., and de Zubicaray, G. L. (2010). Semantic interference in object naming: an fMRI study of the postcue naming paradigm. Neuroimage 50, 796-801.

Howard, D., Nickels, L., Coltheart, M., and Cole-Virtue, J. (2006). Cumulative semantic inhibition in picture naming: experimental and computational studies. Cognition 100, 464-482. 
Humphreys, G. W., Lloyd-Jones, T. J., and Fias, W. (1995). Semantic interference effects on naming using a postcue procedure: tapping the links between semantics and phonology with pictures and words. J. Exp. Psychol. Learn. Mem. Cogn. 21, 961-980.

Huttenlocher, J., and Kubicek, L. (1983). The source of relatedness effects on naming latency. J. Exp. Psychol. Learn. Mem. Cogn. 9, 486-496.

Janssen, N., Bi, Y., and Caramazza, A. (2008a). A tale of two frequencies: determining the speed of lexical access in Mandarin Chinese and English compounds. Lang. Cogn. Process. 23, 1191-1223.

Janssen, N., Schirm, W., Mahon, B. Z., and Caramazza, A. (2008b). Semantic interference in a delayed naming task: evidence for the response exclusion hypothesis. J. Exp. Psychol. Learn. Mem. Cogn. 34, 249-256.

Kroll, J. F., and Stewart, E. (1994). Category interference in translation and picture naming: evidence for asymmetric connections between bilingual memory representations. J. Mem. Lang. 33, 149-174.

Krott, A., Schreuder, R., Baayen, R. H., and Dressler, W. U. (2007). Analogical effects on linking elements in German compounds. Lang. Cogn. Process. 22, 25-57.

La Heij, W., Heikoop, K. W., Akerboom, S., and Bloem, I. (2003). Picture naming in picture context: semantic interference or semantic facilitation? Psychol. Sci. 45, 49-62.

Levelt, W. J. M., Roelofs, A., and Meyer, A. S. (1999). A theory of lexical access in speech production. Brain Behav. Sci. 22, 313-335.

Levi, J. N. (1978). The Syntax and Semantics of Complex Nominals. New York: Academic Press.
Lüttmann, H., Zwitserlood, P., Böhl, A., and Bölte, J. (2011). Evidence for morphological composition at the form level in speech production. $J$. Cogn. Psychol. 23, 818-836.

Mahon, B. Z., Costa, A., Peterson, R., Vargas, K. A., and Caramazza, A. (2007). Lexical selection is not by competition: a reinterpretation of semantic interference and facilitation effects in the picture-word interference paradigm. J. Exp. Psychol. Learn. Mem. Cogn. 33, 503-535.

Malpass, D., and Meyer, A. S. (2010) The time course of name retrieval during multiple-object naming: evidence from extrafoveal-on-foveal effects. J. Exp. Psychol. Learn. Mem. Cogn. 36, 523-537.

Meyer, A. S., and Damian, M. F. (2007). Activation of distractor names in the picture-picture interference paradigm. Mem. Cogn. 35, 494-503.

Meyer, A. S., Ouellet, M., and Häcker, C. (2008). Parallel processing of objects in a naming task. J. Exp. Psychol. Learn. Mem. Cogn. 34, 982-987.

Morsella, E., and Miozzo, M. (2002). Evidence for a cascade model of lexical access in speech production. $J$. Exp. Psychol. Learn. Mem. Cogn. 28, 555-563.

Navarrete, E., and Costa, A. (2005). Phonological activation of ignored pictures: further evidence for a cascaded model of lexical access. J. Mem. Lang. 53, 359-377.

Navarrete, E., and Costa, A. (2009). The distractor picture paradox in speech production: evidence from the word translation task. J. Psycholinguist. Res. 38, 527-547.

Navarrete, E., Mahon, B. Z., and Caramazza, A. (2010). The cumulative semantic cost does not reflect lexical selection by competition.
Acta Psychol. (Amst.) 134, 279-289.

Oppenheim, G. M., Dell, G. S., and Schwartz, M. F. (2010). The dark side of incremental learning: a model of cumulative semantic interference during lexical access in speech production. Cognition 114, 227-252.

Oppermann, F., Jescheniak, J. D. Schriefers, H., and Görges, F. (2010). Semantic relatedness among objects promotes the activation of multiple phonological codes during object naming. Q. J. Exp. Psychol. 63 356-370.

Roelofs, A. (1992). A spreadingactivation theory of lemma retrieval in speaking. Cognition 42, 107-142.

Roelofs, A. (2007). Attention and gaze control in picture naming, word reading, and word categorization. $J$. Mem. Lang. 57, 232-251.

Roelofs, A. (2008). Tracing attention and the activation flow in spoken word planning using eye movements. J. Exp. Psychol. Learn. Mem. Cogn. 34, 353-368.

Schnur, T. T., Schwartz, M. F., Brecher, A., and Hodgson, C. (2006). Semantic interference during blockedcyclic naming: evidence from aphasia. J. Mem. Lang. 54, 199-227.

Schriefers, H., Meyer, A. S., and Levelt, W. J. M. (1990). Exploring the time course of lexical access in production: picture-word interference studies. J. Mem. Lang. 29, 86-102.

Sperber, R. D., McCauley, C., Ragain, R. D., and Weil, C. M. (1979). Semantic priming effects on pic-ture and word processing. Mem. Cogn. 7, 339-345.

Starreveld, P. A., and La Heij, W. (1996). Time-course analysis of semantic and orthographic context effects in picture naming. J. Exp. Psychol. Learn. Mem. Cogn. 22, 896-918.
Vigliocco, G., Vinson, D. P., Lewis, W., and Garrett, M. F. (2004). Representing the meanings of object and action words: the featural and unitary semantic space hypothesis. Cogn. Psychol. 48, 422--488.

Wisniewski, E. J., and Middleton, E. L. (2002). Of bucket bowls and coffee cup bowls: spatial alignment in conceptual combination. J. Mem. Lang. 46, 1-23.

Wisniewski, E. J., and Murphy, G. L. (2005). Frequency of relation type as a determinant of conceptual combination: a reanalysis. J. Exp. Psychol. Learn. Mem. Cogn. 31, 169-174.

Conflict of Interest Statement: The authors declare that the research was conducted in the absence of any commercial or financial relationships that could be construed as a potential conflict of interest.

Received: 30 June 2011; accepted: 23 January 2012; published online: 17 February 2012.

Citation: Aristei S, Zwitserlood $P$ and Rahman RA (2012) Pictureinduced semantic interference reflects lexical competition during object naming. Front. Psychology 3:28. doi: 10.3389/fpsyg.2012.00028

This article was submitted to Frontiers in Language Sciences, a specialty of Frontiers in Psychology.

Copyright (c) 2012 Aristei, Zwitserlood and Rahman. This is an open-access article distributed under the terms of the Creative Commons Attribution Non Commercial License, which permits noncommercial use, distribution, and reproduction in other forums, provided the original authors and source are credited. 


\section{APPENDIX}

\section{Context picture}

\section{Target picture}

der Adler (eagle)

der Apfel (apple)

der Arm (arm)

die Avocado (avocado)

die Axt (axe)

der Balkon (balcony)

der Ball (ball)

die Bank (bench)

der Bohrer (drill)

die Brust (breast)

der Delphin (dolphin)

der Esel (donkey)

der Floh (flea)

der Fluegel (grand piano)

der Foehn (hair dryer)

der Fuchs (fox)

die Gondel (gondola)

der Guertel (belt)

der Hammer (hammer)

die Harke (rake)

der Hase (hare)

der Herd (stove)

der Hocker (stool)

die Hose (pants)

die Hummel (bumble-bee)

der Hummer (lobster)

die Karte (card)

die Katze (cat)

die Kiwi (kiwi)

der Korb (basket)

die Krawatte (tie)

der Kuchen (cake)

der Kuerbis (pumpkin)

die Kuh (cow)

die Kutsche (carriage)

die Lampe (lamp)

der Lauch (leek)

die Leiter (ladder)

der Loeffel (spoon)

die Lok (locomotive)

der Mais (corn)

der Mantel (coat)

die Maus (mouse)

die Moehre (carrot)

die Moewe (seagull)

die Muehle (mill)

der Mund (mouth)

die Muschel (seashell)

der Panzer (tank)

die Paprika (pepper)

\section{Semantically related}

der Papagei (parrot)

der Pfirsich (peach)

der Fuss (foot)

die Gurke (cucumber)

die Zange (pliers)

der Zaun (fence)

der Teddy (teddy)

die Wiege (cradle)

der Pflug (plow)

die Zunge (tongue)

der Hai (shark)

der Widder (ram)

der Kaefer (bug)

der Gong (gong)

der Kam (comb)

der Loewe (lion)

der Bus (bus)

der Ring (ring)

der Spachtel (scraper)

die Saege (saw)

der Biber (beaver)

der Toaster (toaster)

der Stuhl (chair)

die Muetze (hat)

die Libelle (dragonfly)

der Frosch (frog)

die Schaukel (swing)

die Hyaene (hyena)

die Birne (pear)

der Wuerfel (dice)

die Brille (glasses)

der Donut (donut)

der Brokkoli (broccoli)

die Giraffe (giraffe)

die Limousine (limousine)

die Heizung (heater)

der Pilz (mushroom)

die Treppe (stairs)

der Teller (plate)

die Rakete (missile)

der Farn (fern)

der Frack (tailcoat)

die Ziege (goat)

die Bohne (bean)

die Eule (owl)

die Burg (castle)

der Finger (finger)

die Qualle (jellyfish)

der Zeppelin (zeppelin)

die Zwiebel (onion) die Eule (owl)

die Birne (pear)

die Zunge (tongue)

der Pilz (mushroom)

der Spachtel (scraper)

die Treppe (stairs)

die Schaukel (swing)

der Stuhl (chair)

die Saege (saw)

der Fuss (foot)

die Flunder (flounder)

die Giraffe (giraffe)

die Ameise (ant)

die Harfe (harp)

die Buerste (hairbrush)

die Hyaene (hyena)

die Faehre (ferry)

die Brosche (brooch)

die Zange (pliers)

der Pflug (plow)

die Ziege (goat)

die Waage (scale)

die Wiege (cradle)

der Stiefel (boot)

der Skorpion (scorpion)

die Qualle (jellyfish)

der Teddy (teddy)

der Loewe (lion)

der Pfirsich (peach)

die Rutsche (slide)

der Hut (hat)

die Brezel (pretzel)

die Zwiebel (onion)

der Widder (ram)

der Zug (train)

der Teppich (carpet)

die Gurke (cucumber)

der Zaun (fence)

die Reibe (grater)

der Zeppelin (zeppelin)

die Palme (palm tree)

die Weste (waistcoat)

der Biber (beaver)

der Kohl (cabbage)

der Papagei (parrot)

der Tempel (temple)

die Nase (nose)

der Frosch (frog)

die Rakete (missile)

der Brokkoli (broccoli)

\section{Semantically unrelated}

der Spachtel (scraper)

der Gong (gong)

der Toaster (toaster)

die Burg (castle)

die Stirn (forehead)

der Skorpion (scorpion)

der Esel (donkey)

die Gurke (cucumber)

der Storch (stork)

die Saege (saw)

der Stuhl (chair)

der Ball (ball)

der Koffer (suitcase)

der Hase (hare)

der Kohl (cabbage)

der Korb (basket)

der Frosch (frog)

der Papagei (parrot)

der Fuss (foot)

die Ente (duck)

der Fluegel (grand piano)

der Loewe (lion)

der Pilz (mushroom)

die Waage (scale)

die Puppe (doll)

der Schild (buckler)

der Esel (donkey)

die Patrone (cartridge)

die Faehre (ferry)

der Fuchs (fox)

die Reibe (grater)

der Zaun (fence)

der Teddy (teddy)

die Rakete (missile)

die Palme (palm tree)

die Hyaene (hyena)

der Ring (ring)

die Eule (owl)

der Frack (tailcoat)

die Zwiebel (onion)

der Zeppelin (zeppelin)

der Becher (cup)

die Karte (card)

die Heizung (heater)

die Zange (pliers)

die Ziege (goat)

der Tempel (temple)

die Treppe (stairs)

der Brokkoli (broccoli)

die Schaukel (swing) die Zange (pliers

die Harfe (harp)

die Waage (scale)

der Tempel (temple)

der Fuss (foot)

die Eule (owl)

die Maus (mouse)

der Pilz (mushroom)

die Ente (duck)

der Pflug (plow)

die Wiege (cradle)

die Karte (card)

die Box (box)

die Birne (pear)

die Bohne (bean)

die Puppe (doll)

die Nase (nose)

die Qualle (jellyfish)

die Stirn (forehead)

der Storch (stork)

die Trompete (trumpet)

die Giraffe (giraffe)

die Gurke (cucumber)

der Toaster (toaster)

der Korb (basket)

die Peitsche (whip)

die Maus (mouse)

der Stift (pencil)

der Bus (bus)

die Hummel (bumble-bee)

der Teller (plate)

die Treppe (stairs)

die Schaukel (swing)

der Zeppelin (zeppelin)

der Farn (fern)

der Widder (ram)

die Brosche (brooch)

der Skorpion (scorpion)

die Weste (waistcoat)

der Brokkoli (broccoli)

die Rakete (missile)

die Kanne (can)

der Ball (ball)

der Teppich (carpet)

der Spachtel (scraper)

der Stiefel (boot)

die Burg (castle)

der Zaun (fence)

die Zwiebel (onion)

der Teddy (teddy) 


\section{Context picture}

\section{Target picture}

die Patrone (cartridge) der Pavillon (gazebo) die Peitsche (whip) die Pfanne (pan) der Pfau (peacock) die Pizza (pizza) die Puppe (doll) der Ranzen (knapsack) der Roller (scooter) die Sardine (sardine) der Schal (scarf) der Schild (buckler) der Schrank (closet) die Schuerze (apron) die Schuessel (bowl) die Spange (barrette) der Spargel (asparagus) die Spinne (spider) die Spuele (sink) der Stift (pencil) die Stirn (forehead) der Tanga (thong) die Tanne (fir) die Tasche (bag) die Taube (pigeon) der Topf (pot) der Traktor (tractor) die Trompete (trumpet) die Uhr (clock) der Wurm (worm)

\section{Semantically related}

die Lupe (magnifier) der Tempel (temple) die Lanze (lance) die Reibe (grater) der Storch (stork) die Brezel (pretzel) die Rutsche (slide) der Koffer (travel case) der Zug (train) die Flunder (flounder) der Hut (hat) der Helm (helmet) der Teppich (carpet) die Weste (waistcoat) die Kanne (can) die Buerste (hairbrush) der Kohl (cabbage) die Ameise (ant) die Waage (scale) der Block (notepad) der Finger (finger) der Stiefel (boot) die Palme (palm tree) die Box (box) die Ente (duck) der Becher (cup) der Bus (bus) die Harfe (harp) die Brosche (brooch) der Skorpion (scorpion)

der Block (notepad)
die Burg (castle)
der Helm (helmet)
der Teller (plate)
die Ente (duck)
der Donut (donut)
der Wuerfel (dice)
die Box (box)
die Limousine (limousine
der Hai (shark)
die Brille (glasses)
die Lanze (lance)
die Heizung (heater)
der Frack (tailcoat)
der Becher (cup)
der Kamm (comb)
die Bohne (bean)
der Kaefer (bug)
der Toaster (toaster)
die Lupe (magnifier)
die Nase (nose)
die Muetze (hat)
der Farn (fern)
der Koffer (suitcase)
der Storch (stork)
die Kanne (can)
die Faehre (ferry)
der Gong (gong)
der Ring (ring)
die Libelle (dragonfly)

\section{Semantically unrelated}

$\begin{array}{ll}\text { der Donut (donut) } & \text { die Katze (cat) } \\ \text { der Stiefel (boot) } & \text { die Ziege (goat) } \\ \text { die Brezel (pretzel) } & \text { der Hummer (lobster) } \\ \text { die Weste (waistcoat) } & \text { der Frack (tailcoat) } \\ \text { der Zug (train) } & \text { die Limousine (limousine) } \\ \text { die Harfe (harp) } & \text { der Gong (gong) } \\ \text { der Fuchs (fox) } & \text { die Hummel (bumble-bee) } \\ \text { der Kaefer (bug) } & \text { die Ameise (ant) } \\ \text { der Farn (fern) } & \text { die Palme (palm tree) } \\ \text { die Brosche (brooch) } & \text { der Ring (ring) } \\ \text { der Teller (plate) } & \text { die Reibe (grater) } \\ \text { der Hummer (lobster) } & \text { die Brezel (pretzel) } \\ \text { der Widder (ram) } & \text { die Hyaene (hyena) } \\ \text { die Limousine (limousine) } & \text { der Zug (train) } \\ \text { der Wurm (worm) } & \text { die Libelle (dragonfly) } \\ \text { die Bohne (bean) } & \text { der Kohl (cabbage) } \\ \text { der Teppich (carpet) } & \text { die Heizung (heater) } \\ \text { die Box (box) } & \text { der Koffer (suitcase) } \\ \text { die Giraffe (giraffe) } & \text { der Loewe (lion) } \\ \text { der Finger (finger) } & \text { die Nase (nose) } \\ \text { die Axt (axe) } & \text { der Hammer (hammer) } \\ \text { der Pflug (plow) } & \text { die Saege (saw) } \\ \text { die Buerste (hairbrush) } & \text { der Kamm (comb) } \\ \text { die Ameise (ant) } & \text { der Kaefer (bug) } \\ \text { die Lanze (lance) } & \text { der Helm (helmet) } \\ \text { der Wurm (worm) } & \text { die Libelle (dragonfly) } \\ \text { der Frosch (frog) } & \text { die Nase (nose) } \\ \text { der Hase (hare) } & \text { die Birne (pear) } \\ \text { die Oualle (jellyfish) } & \text { der Papagei (parrot) } \\ \text { der Topf (pot) } & \text { die Schuessel (bowl) } \\ & \\ \text { dima } & \end{array}$

